Dicle Tip Dergisi / Dicle Med J (2018) 45 (1) : 103 - 107

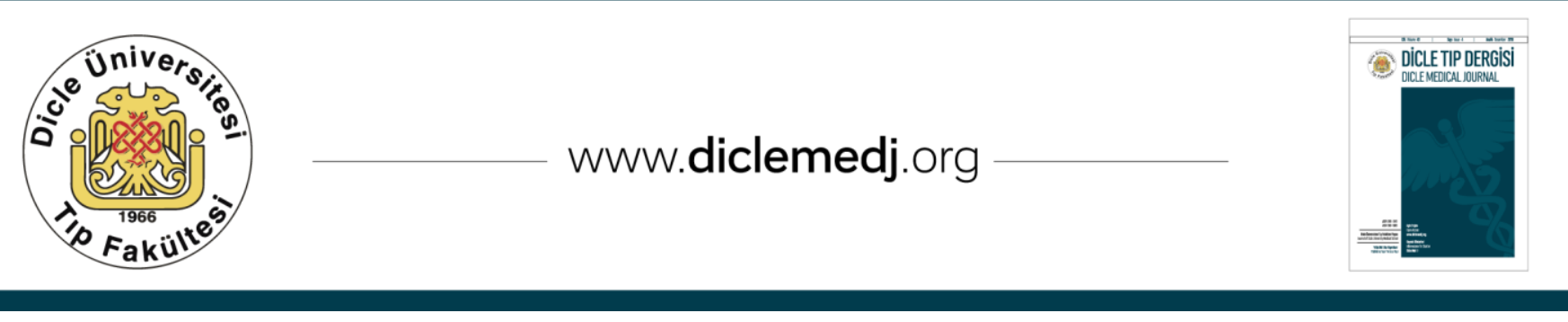

Case Report / Olgu Sunumu

\title{
An Acute Brucellosis Case Presented with Pancytopenia and Hepatitis
}

\author{
Heval Bilek ${ }^{1}$, Ümit Alanbayı ${ }^{2}$, Tayibe Bal ${ }^{3}$ \\ 1 Siirt State Hospital, Infectious Diseases and Clinical Microbiology, Siirt, Turkey, ORCID: 0000-0002-4330-3293 \\ 2 Siirt State Hospital, Medical Microbiology, Siirt, Turkey, ORCID: 0000-0002-7284-8145 \\ 3 Siirt State Hospital, Infectious Diseases and Clinical Microbiology, Siirt, Turkey, ORCID: 0000-0002-5315-122X
}

Received: 13.09.2017; Revised: 05.10.2017; Accepted: 16.10.2017

\begin{abstract}
Brucellosis is a common zoonotic disease in endemic areas like Turkey. It is an infection that can be manifested by extensive clinical findings, for this reason it can be difficult to diagnose. In humans, treatment of the disease requires long-lasting combined antibiotics and appropriate treatment regimens, but it is often difficult to achieve this success in countries with limited resources. Therefore, this may be an important economic burden in terms of both cost of treatment and potential loss of labor in individuals affected by brucellosis. A 23-year-old male patient who was presented with fever, pancytopenia and hepatitis, was hospitalized with the aim of investigating the etiology of fever. On laboratory findings supporting the Brusella disease, we started treatment with the combination of gentamycin and doxycycline to avoid drug-induced hepatotoxic effect. Laboratory findings were successfully improved while clinical complaints decreased. Brucella disease should be kept in mind in in endemic areas, concerning patients with abnormal laboratory findings of the hematopoietic or hepatobiliary system. Taking into consideration the side effects of the medicines used in the treatment of the disease, effective and least toxic combinations should be selected.
\end{abstract}

Keywords: Brucellosis, pancytopenia, hepatitis

DOI: $10.5798 /$ dicletip.363935

Yazışma Adresi / Correspondence: Heval Bilek, Siirt State Hospital, Infectious Diseases and Clinical Microbiology ClinicSiirt, Turkey 5600, e-mail: hevalbilek@gmail.com 


\section{Pansitopeni ve Hepatit ile Başvuran Akut Bruselloz Vakası}

\section{Özet}

Bruselloz, Türkiye gibi endemik bölgelerde yaygın bir zoonotik hastalıktır. Geniş klinik bulgular spektrumu ile ortaya çıkabilen yaygın bir enfeksiyondur ve nedenlerde tanı koymak zor olabilir. İnsanlarda hastalığın tedavisi uzun süren kombine antibiyotik gerektirir ve uygun tedavi rejimleri ile relaps oranları düşüktür, ancak kaynakları sınırlı olan ülkelerde bu başarıyı sağlamak çoğu kez zordur.

$\mathrm{Bu}$ nedenle Bruselloz hastalığı etkilenen bireylerde hem tedavi maliyeti hem de potansiyel işgücü kaybı açısından, önemli bir ekonomik yük olabilir. Ateş, pansitopeni ve hepatit ile başvuran 23 yaşındaki erkek hasta, ateş etyolojisini araştırmak amacıyla yatırıldı. Brusella hastalığını destekleyen laboratuvar bulguları üzerine, ilaç kaynaklı hepatotoksisiteyi önlemek için gentamisin ve doksisiklinin kombinasyonu ile tedaviye bașlandı. Klinik şikayetler azalırken laboratuvar bulguları başarıyla düzeldi. Hematopoetik veya hepatobiliyer sisteme ait anormal laboratuvar bulguları olan hastalarda ve hastalığın endemik olduğu bölgelerde Brucella hastalı̆̆ı akılda tutulmalıdır. Hastalığın tedavisinde kullanılan ilaçların yan etkileri göz önüne alınarak, etkili ve en az toksik kombinasyonları seçilmelidir.

Anahtar kelimeler: Brusellozis, pansitopeni, Hepatit

\section{INTRODUCTION}

Brucellosis is a chronic infectious bacterial disease seen in humans as well as domestic and wild animals. This disease is also called Malta Fever, Bang Disease, Undulant Fever or Mediterranean Fever ${ }^{1}$.

Treatment of the disease requires long-lasting combined antibiotics and appropriate treatment regimens, but it is often difficult to achieve this success in countries with limited resources. Therefore, this may be an important economic burden in terms of both cost of treatment and potential loss of labor in individuals affected by brucellosis².

Although the disease is seen worldwide, it is most often seen in countries that have no appropriate standards developed in the field of public health and animal health protection. The risk of infection is high in the Mediterranean Basin (Portugal, Spain, Southern France, Italy, Greece, Turkey, North Africa), South and Central American countries, Asia, Africa, Caribbean and Near East countries ${ }^{1}$. In countries such as Turkey where the disease is endemic, we think that our case is important in terms of relatively rare clinical manifestations and for alternative antibiotherapy options of the disease.

\section{CASE}

A 23-year-old male patient was admitted to emergency service with the complaints of fatigue, fever and chills lasted for 10 days; then he was admitted to our outpatient clinic after his first examinations performed in the emergency service. In the first examination, patient was completely awake, co-operative and there was no nuchal stiffness. Head and neck examination was normal. His respiratory sounds were rough in both hemithorax. There were no rales/rhonchi. No additional cardiac sound and murmur were observed. In the abdominal examination approximately $2 \mathrm{~cm}$ of liver underneath the lower rib was palpated. There was no obvious pain and sensitivity in the abdomen where Traube's region sound was dull. The fever measured as $37.7^{\circ} \mathrm{C}$. The patient was given parenteral antipyretic with the cause of fever in the emergency service.

In the first laboratory tests of the patient, the results were reported as follows: Leukocyte: 1,39x 109/L, neutrophil: 1,02x109/L, hemoglobin: 13,0 g/dl, hematocrit: 36,5\%, thrombocyte: 28x109/L, Alanine amino transferase (Alt): 71 IU, Aspartate amino 
transferase (Ast): 197 IU, Alkaline phosphatase (Alp): $82 \mathrm{U} / \mathrm{L}$, Gamma glutamyl transferase (Ggt): $69 \mathrm{U} / \mathrm{L}$ and C-reactive protein (Crp): 64 $\mathrm{mg} / \mathrm{L}$. Ultrasonography of the abdomen performed in the emergency service, revealed an increase in liver size of $177 \mathrm{~mm}$ and spleen size of $158 \mathrm{~mm}$. With the aim of investigating the etiology of fever, the patient was admitted to the Infectious Diseases ward. Blood samples for culture were obtained; serologic tests for HIV and Hepatitis A, B, C were studied. The patient was only positive for Anti-HAV IgG. Rose Bengal and Coombs examinations were studied. After Rose Bengal test was reported as positive; treatment of gentamycin $5 \mathrm{mg} / \mathrm{kg}$ intravenouse and doxycycline $2 \times 100 \mathrm{mg} /$ day orally were started with the pre-diagnosis of Brucellosis. In the second day of hospitalization, Coombs test was reported as positive at titration $1 / 640$.

Table I: Liver Function Tests during the treatment days

\begin{tabular}{lcccccc}
\hline & Admission & $1^{\text {st }}$ Day & $2^{\text {nd }}$ Day & $5^{\text {th }}$ Day & $8^{\text {th }}$ Day & $2^{\text {st }}$ Day \\
\hline Alt ( IU) & 71 & 120 & 246 & 322 & 127 & 22 \\
Ast ( IU) & 197 & 389 & 635 & 368 & 59 & 31 \\
Alp (U/L) & 82 & 120 & - & 239 & 168 & 57 \\
Ggt (U/L) & 69 & 148 & 207 & 289 & 158 & 41 \\
\hline
\end{tabular}

Table II: Blood cell counts during the treatment days

\begin{tabular}{lrrrrrr}
\hline & Admission & $1^{\text {st }}$ Day & $2^{\text {nd }}$ Day & $5^{\text {th }}$ Day & $8^{\text {th }}$ Day & $2^{\text {st }}$ Day \\
\hline Leukocyte(109/L) & 1,39 & 1,44 & 2,06 & 4,09 & 4,63 & 5,57 \\
Neutrophil(109/L) & 1,02 & 0,68 & 1,06 & 1,89 & 2,64 & 2,14 \\
Hemoglobin(g/dl) & 13,0 & 12,2 & 12,4 & 14,0 & 12,2 & 14,2 \\
Hematocrit (\%) & 36,5 & 32,5 & 31,7 & 41,6 & 38,2 & 42,4 \\
Thrombocyte(109/L) & 28 & 27 & 45 & 90 & 195 & 180 \\
\hline
\end{tabular}

The results of the blood cultures obtained at admission and on the third day of treatment were reported as Brusella spp. Patient, whose fever reduced after the third day of follow-ups, general condition and laboratory findings were improved. The patient was discharged on the 8th day of admission with doxycycline and rifampicin oral treatment prescribed. The patient applied for clinical control purpose at 3 weeks of antibiotic therapy. Control laboratory values were reported as follows: Leukocyte: 5,57x109/L, neutrophil: 2,14x109/L, hemoglobin: 14,2 $\mathrm{g} / \mathrm{dl}$, hematocrit: 42,4\%, thrombocyte: 180x109/L, Alt: 22 IU, Ast: 31 IU, Alp: $57 \mathrm{U} / \mathrm{L}$, Ggt: $41 \mathrm{U} / \mathrm{L}$, Crp: $1.9 \mathrm{mg} / \mathrm{L}$.
Brusella Coombs test was positive at titration $1 / 640$, as at previous titration. The patient has no active clinical complaints.

\section{DISCUSSION}

Brucellosis is a common zoonotic disease in endemic areas like Turkey. It is an infection that can be manifested by extensive clinical findings, for this reason it can be difficult to diagnose $^{3}$. The most common route of transmission occurs when humans consume unpasteurized milk and products of raw milk from infected animals. The organismstaken to the regional lymph nodes, multiplies there and 
may spread to bone marrow, liver, spleen and other organs in the bloodstream ${ }^{4}$.

Brucella disease is known to cause anemia, leukopenia and less degree of thrombocytopenia and pancytopenia. It is thought that hypersplenism, disseminated intravascular coagulation (DIC), histiocytic hemophagocytosis, bone marrow suppression and destruction of thrombocytes are effective in the formation of pancytopenia seen during the disease. Splenomegaly is seen in $20-40 \%$ of patients, whereas this rate rises to $86-88 \%$ in patients with pansitopenia. This condition makes think that hypersplenism may be the main cause of pancytopenia- ${ }^{5-6}$. Buzgan et al. ${ }^{7}$ reported that the incidence of anemia, leukopenia and thrombocytopenia in patients was found respectively $40.3 \%, 10.9 \%$ and $9.5 \%$ and the incidence of pancytopenia among all cases was 4.9\%. Again in Turkey, Akdeniz et al. ${ }^{8}$ found that the pancytopenia rate was $8 \%$ in the study carried out with 233 patients. This rate was found as $9 \%$ by Özer et al. ${ }^{9}$. In our case; pancytopenia was also accompanied by splenomegaly. The sizes of liver and spleen increased and parenchymal echoes were homogeneous. No solid-cystic mass lesions were observed in both organs. We therefore think that pancytopenia may be due to hypersplenism.

Hepatic involvement in brucellosis covers a wide range from slight elevation of the aminotransferases to granulomatous forms and liver abscess. Increases in aminotransferases were seen in one third and one fourth of the cases while this finding is seen more often in acute phases of the disease. In the study carried out by Buzgan et al. ${ }^{7}$, it was detected that liver enzyme elevation was found to be $24.8 \%$. Clinic can occur as hepatitis in $3 \%$ of cases of Brucellosis with hepatic involvement ${ }^{10}$. Aminotransferase levels of our patient were high at the time of admission, in the way that he would support hepatitis was related to brucellosis. Until the third day after the beginning of the treatment, the enzyme elevation continued by increasing five times higher than normal values. The enzyme values reduced under antibiotic therapy. In Iran, a patient diagnosed with acute brucella hepatitis clinic was successfully treated with two combinations of doxycycline and aminoglycoside and the combination was proposed as the first choice in the treatment ${ }^{11}$. In a similar case reported in Turkey, the patient recovered after 6 weeks treatment with a combination of doxycycline and streptomycin ${ }^{12}$. Aminoglycosides (including streptomycin) are not hepatotoxic. Because there is no tendency of increasing risk of hepatotoxicity in doxycycline, a standard regime including doxycycline instead of ciprofloxacin was recommended to be started $^{11-13}$. In this case we started treatment with the combination of gentamycin and doxycycline to avoid drug-induced hepatotoxic effect.

In conclusion, while fever etiology is being investigated in areas where the disease is endemic, Brucellosis should be kept in mind in patients with abnormal laboratory findings of the hematopoietic or hepatobiliary system. Taking into consideration the side effects of the medicines used in the treatment of the disease, effective and least toxic combinations should be selected.

Declaration of Conflicting Interests: The authors declare that they have no conflict of interest.

Financial Disclosure: No financial support was received.

\section{REFERENCES}

1. Galińska EM, Zagórski J. Brucellosis in humans-etiology, diagnostics, clinical forms. Ann Agric Environ Med. 2013; 20:233-8.

2. de Glanville WA, Conde-Âlvarez R, Moriyon I, et al. Poor performance of the rapid test for human brucellosis in health facilities in Kenya. PLoS Negl Trop Dis. 2017;11: e0005508. 
3. Kaya O, Avsar K, Zeynep Akçam F. Unusual manifestations of brucellosis. Arch Med Sci. 2011;7:173-5.

4. Sözen TH. Bruselloz. Willke Topçu A, Söyletir G, Doğanay M (eds): Infeksiyon Hastalıkları ve Mikrobiyolojisi, 3rd edn. İstanbul: Nobel Basımevi 2002;636-42.

5. Bakri FG, Al-Bsoul NM, Magableh AY,et al. Brucellosis presenting as myelofibrosis: first case report. Int J Infect Dis. 2010;14:e158-60.

6. Sakin A, Çelik K, Öztürk S, et al. Bruselloza bağlı bir febril nötropeni olgusu. Med Bull Haseki 2012;50:6971.

7. Buzgan $\mathrm{T}$, Karahocagil MK, Irmak $\mathrm{H}$, et al. Clinical manifestations and complications in 1028 cases of brucellosis: a retrospective evaluation and review of the literature. Int J Infect Dis. 2010;14:e469-78.
8. Akdeniz H, Irmak H, Demiröz AP. Evaluation of brucellosis cases in Van region of Eastern Anatolia: a-3 year experience. Nagoya Med J.1998;42:101-10.

9. Ozer S, Oltan N, Gencer S. Bruselloz: 33 olgunun değerlendirilmesi. Klimik Derg. 1998;11:82-4.

10. Mandell GL, Douglas RG, Bennett JE. Mandell, Douglas and Bennett's Principles and Practice of Infectious Diseases. 8th edn. Philadelphia: Churcill Livingstone Elsevier, 2015:2583-2589.

11. Keramat F, Hashemi SH. Acute brucellar hepatitis: report of two cases. Avicenna J ClinMicrobInfec. 2015;2:e23908.

12. Ulug M, Celen MK, Ayaz C. An unusual presentation of brucello $\neg$ sis: acute hepatitis. Braz J Infect Dis. 2010;14:641-2.

13. Asef Zadeh M, Allami A, Alavian SM. Acute brucella hepatitis in an urban patient. Hepat Mon.2009;9:310-3. 